
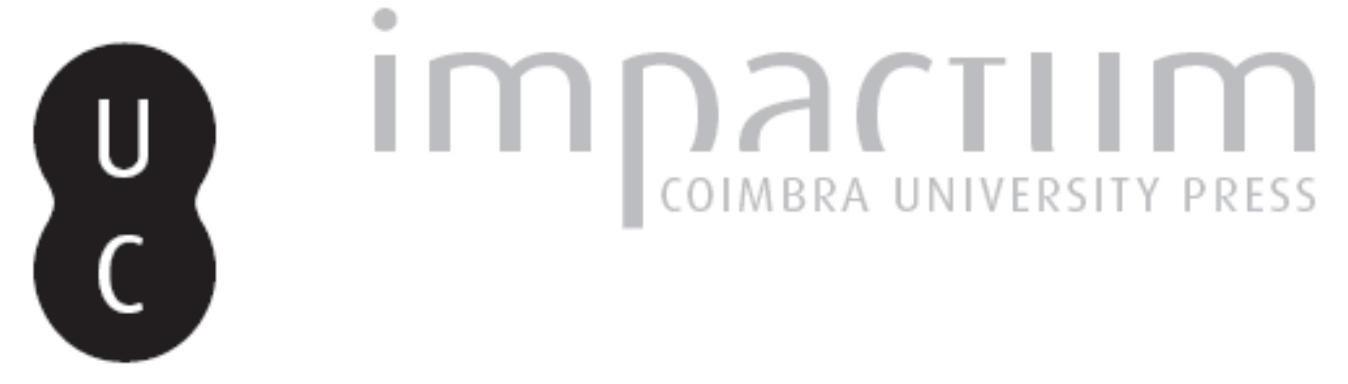

\title{
Can the European Monetary Union get out of the labyrinth?
}

\author{
Autor(es): Biagioli, Mario
}

Publicado por: Faculdade de Direito da Universidade de Coimbra

URL persistente:

URI:http://hdl.handle.net/10316.2/39820

DOI:

DOI:https://doi.org/10.14195/0870-4260_57-1_19

Accessed : $\quad$ 26-Apr-2023 11:17:50

A navegação consulta e descarregamento dos títulos inseridos nas Bibliotecas Digitais UC Digitalis, UC Pombalina e UC Impactum, pressupõem a aceitação plena e sem reservas dos Termos e Condições de Uso destas Bibliotecas Digitais, disponíveis em https://digitalis.uc.pt/pt-pt/termos.

Conforme exposto nos referidos Termos e Condições de Uso, o descarregamento de títulos de acesso restrito requer uma licença válida de autorização devendo o utilizador aceder ao(s) documento(s) a partir de um endereço de IP da instituição detentora da supramencionada licença.

Ao utilizador é apenas permitido o descarregamento para uso pessoal, pelo que o emprego do(s) título(s) descarregado(s) para outro fim, designadamente comercial, carece de autorização do respetivo autor ou editor da obra.

Na medida em que todas as obras da UC Digitalis se encontram protegidas pelo Código do Direito de Autor e Direitos Conexos e demais legislação aplicável, toda a cópia, parcial ou total, deste documento, nos casos em que é legalmente admitida, deverá conter ou fazer-se acompanhar por este aviso.

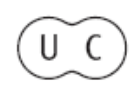




\section{UNIVERSIDADE DE COIMBRA}

FACULDADE DE DIREITO

\section{BOLETIMDECIÊNCIASECONÓMICAS}

HOMENAGEM AO PROF. DOUTOR ANTÓNIO JOSÉ AVELÃS NUNES

VOLUME LVII Tomo I

$\begin{array}{llll}2 & 0 & 1 & 4\end{array}$

Organizadores:

Luís Pedro Cunha

José Manuel Quelhas

Teresa Almeida 


\section{CAN THE EUROPEAN MONETARY UNION GET OUT OF THE LABYRINTH?}

\section{Introduction}

The Eurozone was hit by the world economic crisis of 2008 more severely than any other part of the world and now risks falling back into recession. In this paper I will argue that the reason for its poor performance is that under a fixed exchange-rate régime - of which a Monetary Union is an extreme version - monetary policy is effective in recovering equilibrium only after money shocks. In the face of real shocks, like the ones produced by the world recession of 2008-2010, either some kind of exchange rate flexibility or public measures able to correct the effects of the shocks without leading to recession are required to correct the asymmetries that inevitably appear among the countries and the areas of the Union.

European Union policy laid down by the Maastricht Treaty did not provide any degree of flexibility to face real crisis. Maastricht regulations reinforced the characteristics of a Monetary Union conceived to act in a world where real shocks would not occur. The Treaty was based on a model of "new" classical macroeconomic theory, that markets are rational and self-correcting ${ }^{1}$.

1 This view was proved to be incorrect by the worldwide recession after the monetary crisis starting in the second half of 2007, but this did not change the project underpinning European Union. 
The European Monetary Union (EMU) was regarded as a first step towards European Union (EU) and policy-makers believed it would lead to the elimination of imbalance among European countries. When this did not occur, because the world had moved on from a financial crisis to real side shocks, European policy-makers did not change their view, and are still expecting that the situation will return to "normal": a world without real shocks. This however is not happening, and their stubborn convictions are putting at risk the entire EU architecture and further worsening imbalances between European countries.

In what follows I review the traditional theory of the effects of external imbalances on internal balance. I first consider the 1940s "Keynes Plan" drafted to rebuild the international monetary order brought down by the collapse of the "gold standard" in the 1930s. In Section Two I examine the theory of "optimum currency areas" and approaches of various schools of macroeconomic thought, and compare these with today's European project. In Section Three this theory is used to examine the present-day situation of European Member States (MS) faced with a régime of fixed exchange rates among themselves and flexible exchange rates towards the rest of the world. The conclusion is that it makes for the worst possible world for some MS and places strain onto the entire euro area as long as real shocks occur. This situation will prevail unless the world economy returns to the way it was when the European economic project was originally conceived. Unless this past situation returns, weaker Eurozone MS risk remaining in depression, and depression is likely to spread to the rest of the area through contagion, both real and financial. Section Four discusses the possibility that the strategy of "fiscal consolidation", currently being followed by European policy-makers, might work and restore full equilibrium (domestic plus external equilibria) in the Eurozone. The conclusion is that it is very unlikely to be effective. The last 
section draws some conclusions and provides indications useful for future research.

\section{The Traditional Theory of International Macroe- conomic Re-Adjustment and the European Policy Project}

\subsection{The "Keynes Plan" for an International Cle- aring Union}

The Great Depression of the 1930s inspired the Keynesian revolution in macroeconomic theory, which became the study of how first best equilibrium conditions could be reached, by way of State intervention where markets were failing to produce them. Keynes indicated full employment as the equilibrium to aim at domestically and current account balance as the external equilibrium. He showed how economies can reach internal equilibrium in the General Theory of Employment, Interest and Money (Keynes, 1936) by replacing an expansionist ratio between effective (aggregate) demand and aggregate supply at the domestic level for a contractionist ratio. His next aim was to find out how to co-ordinate the action of domestic policy-makers at the international level, so as to reach international equilibrium without forcing any country to abandon domestic equilibrium. The result was the so-called "Keynes Plan".

The Keynes Plan was drawn up over a period of more than three years, and appeared in several versions (see Keynes, Collected Papers, Vols. XXIII, XXIV and XXV). All versions however aimed to provide for a symmetrical adjustment rule for imbalances in the balance of payments. Keynes believed that the main asymmetry that had led to the collapse of the gold standard was that under the rules fixed by that exchange rate régime, adjustment was "compulsory for the debtors and 
voluntary for the creditors" ${ }^{2}$. Keynes believed that the custom of many creditor countries of sterilizing their surpluses, neither spending in buying goods from debtor countries or lending surplus to debtor countries, had been the cause of the collapse of the gold standard. His plan aimed at a Clearing Union, and its depositors were to be national central banks. The Clearing Union was to have all the characteristics of a national central bank, especially the function of issuing international money termed "bancor". "Bancor" was to be used only to pay debts of the countries running current account deficits, and would not be convertible into gold or any currency used to build up international reserves. The aim of the Clearing Union for Keynes would be to clear international accounts, and its responses to current account imbalances were to be decisive. It would have three possible courses of action: (1) Provide cheap overdraft facilities to debtor countries. (2) Prevent creditor countries from sterilizing their surpluses, by charging them high and rising interest rates on credits occasionally kept in their accounts for long periods. (3) Exert a pressure on debtor countries to clear their external balance, by raising interest rates on overdrafts for excessive and long-lasting debt positions ${ }^{3}$. The Clearing Union would thus have pushed countries to restore external equilibria without hampering internal equilibrium, contrary to the indication of the "quantity theory of money" that external imbalances could be solved by reducing domestic wages and prices. In this way, international competitiveness would be restored in countries facing current account deficits

2 This point is discussed in detail by SkIDELSKY and Joshi (2010).

3 A final indication was that persistently debtor countries would be under pressure to devalue their currency and persistently creditor countries under pressure to revalue, again with the aim of clearing international accounts. 
and external debts, although at the risk of abandoning domestic equilibrium and pushing these countries into recession.

So the Keynes Plan aimed at clearing international balances by preventing countries from being either persistent debtors or persistent creditors. A further corollary was the indication that "control of capital movements, both inward and outward, should be a permanent feature of the system" (Keynes, 1943, p. 72). This was to prevent speculation from destabilizing and breaking up the system.

\subsection{The Treaty of Bretton Woods and the Theory of "Optimum Currency Areas"}

The Treaty signed at Bretton Woods differed markedly from the one envisaged by Keynes; the two central points of the Keynes Plan were de facto abandoned. First, the monetary institution it set up, the International Monetary Fund, IMF, was not given the role of lender of last resort that a national central bank usually holds, and which Keynes intended the Clearing Union to have. Secondly, the burden of adjustment was placed wholly with debtor countries, as had been the case under the gold standard. Creditors were left free to use their accumulating balance of payments surplus as they wished. The reason for these provisions is clear: the United States wished the dollar to become the reserve currency of the international monetary system ${ }^{4}$.

The Bretton Woods System was criticized by several economists. FrIEDMAN (1953) was perhaps the most succes-

4 In the early years of the Bretton Woods system, the United States, despite being the world's main creditor, did not use this privilege to bring about austerity as the solution to the external balance problem of the other members of the system. The system in fact was successful in that period. See below for further discussion. 
sful critic, although his argumentation was different from Keynes' in the previous decade. Keynes argued that a monetary system based on fixed exchange rates would be unable to deal with real shocks without recourse to exchange rates changes ${ }^{5}$. Friedman argued that changes in exchange rates are more effective than changes in wages and prices, although both are effective, as changing just one price is easier than changing the whole set of wages and prices. This argument is similar to the traditional quantity theory of money.

Mundell (1961) developed this point in a "neo-classical synthesis" vein. He envisaged a world in which both fixed and flexible exchange rates are required to eliminate external imbalances, but where some countries may gain from joining a currency area, either sharing a common currency and a common central bank or by keeping different currencies and coordinating their monetary policies. (The EMU was to differ from Mundell's idea in that the European Central Bank does not have "note-issuing powers"). Mundell investigated criteria a country should use to join a "currency area" and how this area should work in order to be "optimal".

Mundell's main finding was that policy makers can pursue the target of reaching full employment in all the member countries of a currency union only if the surplus countries accept inflation (Mundell, 1961, pp. 658-659). He explained this as follows. Suppose that an asymmetrical real shock occurs involving two countries starting from a situation of both internal and external equilibrium (i.e. starting with both full employment and balance-of-payments equilibrium).

5 This point had been dealt with at Bretton Woods. The rules envisaged the possibility that external imbalances could be eliminated through exchange rate changes, provided that they were "structural" and that the rest of the countries in the International Monetary System agreed with the change. 
Hypothesize that the competitiveness of Country A increases, while the competitiveness of Country B, decreases, so that Country A will run a surplus and B a deficit and an amount of money equal to the opposite imbalances will shift from Country B to A. If A sterilizes the increase of money, in B money supply becomes lower than money demand, the interest rate rises, aggregate demand falls, output decreases and unemployment appears. Only where Country A does not sterilize the increase of money supply can Country B aim at maintaining internal balance (i.e. full employment). In this case, however, in A the supply of money exceeds demand and since both countries started from full employment, this will produce, at least in the medium term, increasing prices. This is not necessarily bad for the external equilibrium of either country, as an increase of A's prices reduces the productivity gap in favor of $B$ and decreases the external imbalance between the two countries.

So both Keynes and Mundell, although starting from different theoretical points of view ${ }^{6}$, reached the conclusion that if a currency union pursues the two targets of domestic and external equilibria, policy measures have to be coordinated between surplus and deficit countries and to some extent the cost should be shared between the two groups of countries.

6 Mundell's paper is typical product of the "neo-classical synthesis". This approach constituted the main attempt to combine the "old" quantity theory of money view with the "new" Keynesian view. It restricted the validity of the Keynesian theory to the short-run while hypothesizing that in the long-run domestic equilibrium would be restored in one of two ways. One way was that governments would use short-run demand policies; Samuelson and Meade were the most influential economists taking this view. Alternatively, time would be allowed for all markets, included the slowest, i.e. the labor market, to reach equilibrium, Modigliani and Patinkin being the most influential holders of this view. 
Subsequent literature extended the analysis of the conditions required to optimize the working of a monetary union. A summary can be found in De Grauwe (1992 and subsequent editions); below we simply list the conditions. One group emphasized a high level of uniformity, brought about by competitiveness in goods and in productive factors, including country members' markets. These conditions are as follows: (1) MEADE (1957) maintained that high labor mobility was required to maintain equilibrium in the market labors of both surplus and deficit countries so that unemployed workers from the deficit country can migrate to the surplus country and the balance between supply and demand be restored in both countries ${ }^{7}$. (2) Other authors underlined the key role of financial mobility in stabilizing and tending to equalize, interest rates between currency union members, and thus easing the re-adjustment of monetary disequilibria. (3) McKinnon (1963) stressed that a high degree of openness was required for a good working of an optimum currency area in order to align wages and prices between members and make competition more effective throughout the area. (4) Corden (1972) and others pointed out the importance of convergence of Phillips natural rates of unemployment and inflation rates between country members. These conditions were widely accepted by theorists of the optimum currency area theory.

Much more controversial was the role of fiscal policy. On this issue there was heated debate between Keynesian and neo-classical theorists. MundeLl did not assign to fiscal policy

7 Of course, Meade and other authors making this point tended to underline that this condition had been decisive in previous experiences of monetary unions (the United States, Germany and Italy) but was unlikely to work with European Union, where workers speak different languages and have different customs and habits. 
a particular role in the workings of currency areas ${ }^{8}$. Keynesians, on the other hand, gave more importance to fiscal measures, and considered "automatic stabilizers", usually part of the public accounts of countries applying welfare systems (progressive taxation on income; contribution to unemployed productive factors, etc.) the key to alleviating the cost of asymmetrical shocks. With a high common fiscal budget, surplus areas tend to pay higher taxes, and deficit areas pay lower taxes and obtain welfare contributions (KENEN, 1969, who emphasized also the role played by product differentiation between country members as a way to reduce asymmetrical shocks).

KALDOR (1971) was one of the fiercest critics of the view that fiscal policy was relatively unimportant for the efficient working of currency areas, and of the European project. At the Hague summit of December 1969 the Heads of State and Government agreed to create a "full economic and monetary union" of the "European Community" moving towards economic unification of the six members countries. The "Werner Committee" suggested a three stages plan: the first to bring about monetary union, the second tax harmonization and the third central control over national budgets ${ }^{9}$. Kaldor (1971, reprinted in 1979) believed that this route to Monetary Union, i. e. integrating the money markets of European coun-

8 In Mundell's basic model, based on adaptive expectations and perfect international capital mobility, interest rates were equalized in a world-wide capital market. Financial capital movements moved towards countries where money demand exceeded supply, making it possible for countries to adopt expansionary fiscal policy measures if required.

9 In the Werner Plan, each phase took three years, so the time predicted for the complete process was nine years. In fact, as we shall see later, the time span required for the European Union has been much longer and is now widely expected to become even longer still. 
tries, while limiting Fiscal Union to tax harmonization and control on domestic fiscal policies, "was the basic contradiction of the whole plan" (KALDOR, 1979, p. 204). He argued, "envisaging that the scale of provision of public services...cannot be done with equal rates of taxation unless all Community members are equally prosperous and increase their prosperity at the same rate as the other members... the taxation of the less prosperous and/or the slower-growing countries is bound to be higher (or rise faster) than that of the more prosperous (or faster-growing) areas", and this behavior will inevitably "generate a vicious circle, since with rising taxation the slow-growing areas become less competitive and fall behind even more, thereby necessitating higher social expenditures (on unemployment benefits, etc.) and more restrictive fiscal policies. A system on these lines would create rapidly growing inequalities between the different countries and is bound to break down in a relatively short time. This is another way of saying that the objective of a full monetary and economic union is unattainable without a political union." Kaldor advocated real "fiscal integration, and not just fiscal harmonization" so that "the cumulative tendencies to progress and decline be held in check by a "built-in" fiscal stabilizer which makes the "surplus" areas provide automatic fiscal aid to the "deficit" areas.” (KALDOR, 1979, pp. 204-205).

\subsection{The European Union Policy Project: An Independent European Central Bank über alles}

None of the policy measures indicated by the optimum currency area theory have been followed in building the EMU. Mundell's advice that both surplus and deficit countries should participate in the re-adjustment project and that demand policies should be used to achieve full employment 
was ignored, as was Keynesians' advice that fiscal policy should complement monetary policy in managing the currency area towards optimality. The project of European economic integration has followed a completely different path.

The route to the adjustment of external disequilibria followed by European policy-makers was, and still is, based on targets planned in four phases:

- One phase preceding EMU (1995-1998) having the aim of achieving, or at least approaching five joint targets considered pre-conditions for the optimal working of the Union by all member countries. The five targets were: a degree of convergence of inflation rates and interest rates; reduction of the public balance to under 3\% of the GDP and reduction of the ratio between public debt and GDP to $60 \%$; keeping the exchange rate fixed in the period preceding EMU. These targets implied that (a) monetary convergence among member states and (b) limits on domestic fiscal policies would be imposed.

- Implementation of EMU (1999 onwards) through the ECB. The ECB would manage a common monetary policy with the sole aim of keeping the European inflation rate as low as possible (around 2\%) and giving less relevance to other targets, called "secondary" by ECB such as the dynamics of GDP or unemployment, differently from what is made, for instance, by the Federal Reserve in the United States.

- Restraint of fiscal expansion policies, initially embedded in the "Stability and Development Pact", 1998. EMU members agreed to continue to pursue the two aims of keeping the ratio of "public deficit to GDP" under 3\% and to approach the target of keeping the ratio of "public debt to GDP" close to $60 \%$. The restraint was further strengthened in 2005 and from 2011 onwards, when Maastricht Treaty provisions were implemented, through the Six Pack (2011), the "Fiscal Compact" (Pact on Stability, 
Co-ordination and Governance, 2012) which brings the risk of making European fiscal policy recessionary, and the Two Pack. The start of a common fiscal policy, including the adoption of measures sustaining aggregate effective demand financed through the emission of Eurobond, has been postponed to the time when the targets indicated in these Pacts are reached by all member countries.

- Policies aimed at sustaining growth are incorporated into supply measures, aiming at reducing the "cost of labor per unit produced" in line with the Lisbon strategy, $2000{ }^{10}$. The first problem is that this can be achieved in two very different ways; either by enhancing productivity improvements or by reducing wages, which tends to lower demand and thus worsens the recessionary effects of fiscal austerity. The second problem is that supply measures are pursued at a national level. The complete failure of this aspect of the European policy has led to impasse of the Eurozone project, as described below.

The Eurozone project was to unify European monetary policy, limiting the possibility of expansionary fiscal policy and placing strict limits on domestic policy-makers. It also substituted aggregate demand policies with aggregate supply measures, again under the responsibility of domestic policy-makers. The actual project was in fact less reminiscent of the theory of optimum currency area and more reminiscent of the "Werner Plan" and the idea that fiscal policy should be dealt with at a domestic level, despite the criticism made by Kaldor almost 30 years earlier.

10 "The union has today set itself a new strategic goal for the next decade: to become the most competitive and dynamic knowledge-based economy in the world, capable of sustainable economic growth with more and better jobs and greater social cohesion" (Lisbon Declaration, 24 March 2000). 
We now discuss the theoretical underpinnings of the Maastricht Treaty and the subsequent additions. The Treaty was conceived as a strict application of the neo-liberal ideology which led the world into the global financial crisis of 2007-2010. This ideology, expressed by the New Classical School of Macroeconomics, can be summarized in three main propositions: (1) the rational expectations hypothesis, according to which economic agents can predict correctly the effects of economic policy measures; (2) the real business cycle hypothesis, according to which any economic cycle is produced only by real shocks, and "rational" economic agents reacting to these by modifying their maximizing utility behavior; (3) the efficient market hypothesis, which is the consequence of the first two and holds that markets will always restore the "efficient" first best solution (implying, inter alia, that markets always clear at the point in which demand equals supply). The implications of these three hypotheses are: (1) The main instrument of economic policy should be a monetary program aimed at controlling liquidity and avoiding inflation; (2) Fiscal policy should aim to restrain public deficit and reduce public debt so as not to "crowd out" private investments; (3) All markets should be deregulated in order to increase their flexibility. While in the rest of the world this ideology was more or less abandoned during the crisis in favor of more pragmatic policies, in Europe it was reformulated into a moralistic distinction between "virtuous" countries which benefited from balance of payments surpluses and "sinful" countries which have to pay for their sins, measured by their balance-of-payment deficits. The harmful effects produced by this over-simplified doctrine are examined below.

This view means that monetary convergence at the lowest possible level of inflation and reducing public spending are necessary and sufficient conditions for the attainment of real economy targets, high GDP growth and low unemployment. 
It is this program that is termed by the media "virtuous austerity" and which has been pursued until now by European policy-makers.

Unfortunately, however, the policy has not been effective. This is specifically because in the first decade of EMU, while the monetary indicators cited by the Maastricht Treaty were in fact converging, a big real side shock was developing in the Eurozone. The competitive strengths of member states were changing because of their widely differing dynamics in costs and prices. The effects of these divergences were moreover exacerbated by the worldwide recession of 2008-2010.

Table 1 reports the dynamics of unit labor costs in EMU countries.

\section{Table 1 - Unit Labor Cost (Index Numbers - $2000=100): 2000-2010$}

\begin{tabular}{|l|c|c|c|c|}
\hline \multirow{2}{*}{ Countries } & \multicolumn{4}{|c|}{ Unit Labor Cost (Index number - 2000 = 100) } \\
\cline { 2 - 5 } & $\mathbf{2 0 0 0}$ & $\mathbf{2 0 0 4}$ & $\mathbf{2 0 0 7}$ & $\mathbf{2 0 1 0}$ \\
\hline Austria & 100.0 & 96.4 & 96.6 & 100.4 \\
\hline Belgium & 100.0 & 100.9 & 102.8 & 107.6 \\
\hline Finland & 100.0 & 100.3 & 100.0 & 108.8 \\
\hline France & 100.0 & 100.4 & 103.8 & 106.3 \\
\hline Germany & 100.0 & 95.7 & 88.9 & 91.3 \\
\hline Greece & 100.0 & 105.8 & 109.2 & 115.7 \\
\hline Ireland & 100.0 & 107.6 & 115.0 & 111.5 \\
\hline Italy & 100.0 & 107.8 & 110.8 & 119.0 \\
\hline Netherlands & 100.0 & 106.0 & 106.3 & 110.8 \\
\hline
\end{tabular}




\begin{tabular}{|l|c|c|c|c|}
\hline \multirow{2}{*}{ Countries } & \multicolumn{4}{|c|}{ Unit Labor Cost (Index number - 2000 = 100) } \\
\cline { 2 - 5 } & $\mathbf{2 0 0 0}$ & $\mathbf{2 0 0 4}$ & $\mathbf{2 0 0 7}$ & $\mathbf{2 0 1 0}$ \\
\hline Portugal & 100.0 & 107.5 & 105.9 & 111.6 \\
\hline Spain & 100.0 & 106.8 & 111.2 & 111.3 \\
\hline
\end{tabular}

Source of data: Eurostat

The gap between Germany and the rest of the Eurozone is immediately apparent. Germany had enforced a policy of wage containment (German wages were in fact higher than elsewhere) and reduction of workers' rights since the 1990s. It has been estimated by ILO $(2013$, p. 46) that in the period 1991-2011 all productivity gains in German industry accrued to enterprises, while monthly wages remained unchanged in real terms ${ }^{11}$. This led to a significant increase in German investments, as the public deficit was kept low by German austerity fiscal policies and demand was kept high by world GDP increase due to the worldwide expansion of the first years of the 2000s. High investments increased productivity, and this trend, coupled with falling wages, brought about a significant decrease of German unit labor costs. Other countries (with the possible exception of Austria in the first phase) did not pursue this policy and did not follow this trend, and unit labor costs were either unchanged (Finland, Belgium and, more or less, France) or increasing (all the remaining countries, with Ireland leading until 2007). By the end of the decade (2010) the differences had become enormous: unit labor cost had decreased by almost $10 \%$ in Germany and increased by

11 It should be added that this result was partially due to the reduction of hours worked per worker. 
over 10\% in Greece, Portugal, Ireland, Spain and Netherlands, and by as much as $19 \%$ in Italy.

The divergence in unit labor costs had big repercussions on foreign trade. Table 2 reports the trade balance (current account as a percentage of GDP) of EMU member countries 2003-2011. The complete failure of the Lisbon Strategy is clear. The Eurozone had started the XXI century as a surplus area and the Lisbon Declaration announced the intention of improving this position by way of export led growth as Germany post-World War II. But in fact, the Eurozone balance of payments position fell from a surplus of 1\% of GDP to a deficit of $0.5 \%$ in just eight years ${ }^{12}$.

\section{Table 2 - Commercial Balance in the Euro Area: 2003-2011}

\begin{tabular}{|l|c|c|c|c|}
\hline \multirow{2}{*}{ Countries } & \multicolumn{4}{|c|}{ Trade Balance (Current Account as a \% of GDP) } \\
\cline { 2 - 5 } & $\mathbf{2 0 0 3}$ & $\begin{array}{c}\text { Average } \\
\mathbf{2 0 0 3 - 2 0 0 6}\end{array}$ & $\begin{array}{c}\text { Average } \\
\mathbf{2 0 0 7 - 2 0 1 0}\end{array}$ & $\mathbf{2 0 1 1}$ \\
\hline Euro Area & 1.0 & 0.4 & -0.4 & -0.5 \\
\hline Austria & 0.3 & 0.4 & 3.1 & 3.0 \\
\hline Belgium & 4.6 & 4.0 & -2.4 & 1.4 \\
\hline Finland & 7.8 & 5.2 & 3.8 & 1.9 \\
\hline France & 1.8 & 0.1 & -1.7 & -1.7 \\
\hline Germany & 2.3 & 3.1 & 6.2 & 5.7 \\
\hline Greece & -7.8 & -7.3 & -12.3 & -10.3 \\
\hline
\end{tabular}

12 The table does not report for the next two years, when the Eurozone returned to an albeit modest surplus, as we believe that this was due more to the depression of Eurozone countries than to a recovery of their competitive position. 


\begin{tabular}{|l|c|c|c|c|}
\hline \multirow{2}{*}{ Countries } & \multicolumn{4}{|c|}{ Trade Balance (Current Account as a \% of GDP) } \\
\cline { 2 - 5 } & $\mathbf{2 0 0 3}$ & $\begin{array}{c}\text { Average } \\
\mathbf{2 0 0 3 - 2 0 0 6}\end{array}$ & $\begin{array}{c}\text { Average } \\
\mathbf{2 0 0 7 - 2 0 1 0}\end{array}$ & $\mathbf{2 0 1 1}$ \\
\hline Ireland & -0.8 & -1.4 & -4.3 & 0.5 \\
\hline Italy & -0.6 & -1.1 & -2.9 & -3.5 \\
\hline Netherlands & 2.4 & 4.4 & 6.4 & 6.6 \\
\hline Portugal & -7.2 & -7.6 & -1.2 & -10.0 \\
\hline Spain & -2.4 & -4.3 & -8.5 & -4.6 \\
\hline
\end{tabular}

Source of data: IMF

For understanding the impasse reached by European policy today, the divergence among different MS is even more important than the failure of the Lisbon strategy. The countries where unit labor costs decreased during the decade, particularly Germany, steadily increased their surpluses, while the rest of Eurozone countries suffered from their fall in competitiveness. Even countries that at the beginning of the period enjoyed a safe surplus situation, like Finland, Belgium and France, at the end of the period saw their position worsened or even reversed. France, for example, moved from a surplus to a deficit. Others started with in some cases small deficits, which grew rapidly. Last but not the least, the overseas deficit was mainly located inside the Eurozone, as 2/3 of the surplus that Germany was so successful in reaching comes from other members of the Eurozone. This reflected the changes in levels of competitiveness (Table 1), which could not be counter-balanced through devaluation of national currencies, as had previously been possible for most of the Eurozone members.

The world recession of 2008-2010 worsened the effects on the real shocks and the external imbalances. Public spending had to be raised in countries facing recession in order 
to counterbalance the fall in GDP brought about by recession and consequent decrease in taxes levied. The recession, which had started in the United States and in the private sector, caused serious imbalances in public accounts. The Treaty of Maastricht set the target ratio between public debt and GDP as under $60 \%$, but the ratio in the Eurozone in fact increased, on average, from $72 \%$ to almost $90 \%$. This placed enormous strain on the Eurozone and persuaded Eurozone policy-makers to further restrain fiscal measures in order to pursue the $60 \%$ target.

Tables 3 and 4 report the effects of the crisis on GDP and unemployment, comparing Euro data to data from the four other main economies - the United States, Sweden and the United Kingdom (two members of the EU but not of EMU) and Japan. They show how the effects of the recession were similar in the crucial period 2008-2010, but much worse in the Eurozone than elsewhere in the next three years. Unlike the other areas, the Eurozone fell into a new recession in 2011, and is still not growing on average today, six years after the beginning of the world recession. Moreover, European unemployment has doubled since 2007, while elsewhere it has almost recovered to pre-recession levels.

\section{Table 3 - GDP Yearly Percentage Changes: 2006-2013}

\begin{tabular}{|l|c|c|c|c|}
\hline \multirow{3}{*}{ Countries } & \multicolumn{4}{|c|}{ GDP Percentage Changes: 2006-2013 } \\
\cline { 2 - 5 } & $\begin{array}{c}\text { Average } \\
\mathbf{2 0 0 6 - 2 0 0 7}\end{array}$ & $\begin{array}{c}\text { Average } \\
\mathbf{2 0 0 8 - 2 0 0 9}\end{array}$ & $\begin{array}{c}\text { Average } \\
\mathbf{2 0 1 0 - 2 0 1 1}\end{array}$ & $\begin{array}{c}\text { Average } \\
\mathbf{2 0 1 2 - 2 0 1 3}\end{array}$ \\
\hline Euro Area & +3.0 & -2.0 & +1.8 & -0.6 \\
\hline Austria & +3.7 & -1.2 & +2.3 & +0.6 \\
\hline Belgium & +2.8 & -1.4 & +2.1 & 0.0 \\
\hline
\end{tabular}




\begin{tabular}{|l|c|c|c|c|}
\hline \multirow{2}{*}{ Countries } & \multicolumn{4}{|c|}{ GDP Percentage Changes: 2006-2013 } \\
\cline { 2 - 5 } & $\begin{array}{c}\text { Average } \\
\mathbf{2 0 0 6 - 2 0 0 7}\end{array}$ & $\begin{array}{c}\text { Average } \\
\mathbf{2 0 0 8 - 2 0 0 9}\end{array}$ & $\begin{array}{c}\text { Average } \\
\mathbf{2 0 1 0 - 2 0 1 1}\end{array}$ & $\begin{array}{c}\text { Average } \\
\mathbf{2 0 1 2 - 2 0 1 3}\end{array}$ \\
\hline Denmark & +2.5 & -3.2 & +1.3 & 0.0 \\
\hline Finland & +4.8 & -4.1 & +3.1 & -1.2 \\
\hline France & +2.4 & -1.6 & +1.8 & +0.1 \\
\hline Germany & +3.5 & -2.0 & +3.7 & +0.6 \\
\hline Greece & +4.5 & -1.6 & -6.0 & -5.5 \\
\hline Ireland & +5.3 & -4.3 & +0.6 & -0.1 \\
\hline Italy & +2.0 & -3.3 & +1.1 & -2.1 \\
\hline Luxembourg & +5.7 & -3.1 & +2.5 & +0.9 \\
\hline Netherlands & +3.6 & -1.0 & +1.2 & -1.0 \\
\hline Portugal & +1.9 & -1.4 & +0.3 & -2.3 \\
\hline Spain & +4.8 & -1.4 & -0.1 & -1.4 \\
\hline Sweden & +3.8 & -2.8 & +4.8 & +1.2 \\
\hline UK & +3.1 & -3.0 & +1.4 & +1.0 \\
\hline Japan & +1.9 & -3.2 & +2.1 & +1.4 \\
\hline USA & +2.3 & -1.5 & +2.1 & +2.3 \\
\hline
\end{tabular}

Source of data: IMF and Eurostat

Table 4 - Unemployment: 2002-2013

\begin{tabular}{|l|c|c|c|c|}
\hline \multirow{2}{*}{ Countries } & \multicolumn{4}{|c|}{ UNEMPLOYMENT } \\
\cline { 2 - 5 } & $\mathbf{2 0 0 2}$ & $\mathbf{2 0 0 7}$ & $\mathbf{2 0 1 0}$ & $\mathbf{2 0 1 3}$ \\
\hline Euro Area & 8.5 & 7.5 & 10.1 & 12.0 \\
\hline Austria & 4.2 & 4.4 & 4.4 & 4.9 \\
\hline Belgium & 7.5 & 7.5 & 8.3 & 8.4 \\
\hline
\end{tabular}




\begin{tabular}{|c|c|c|c|c|}
\hline \multirow{2}{*}{ Countries } & \multicolumn{4}{|c|}{ UNEMPLOYMENT } \\
\hline & 2002 & 2007 & 2010 & 2013 \\
\hline Denmark & 4.6 & 3.8 & 7.3 & 7.0 \\
\hline Finland & 9.1 & 8.0 & 8.4 & 8.2 \\
\hline France & 8.3 & 8.0 & 9.3 & 10.3 \\
\hline Germany & 8.7 & ' 8.7 & 7.1 & 5.3 \\
\hline Greece & 10.3 & 8.3 & 12.6 & 27.3 \\
\hline Ireland & 4.5 & 4.7 & 13.9 & 13.1 \\
\hline Italy & 8.5 & 6.1 & 8.4 & 12.2 \\
\hline Luxembourg & 2.6 & 4.2 & 4.6 & 5.8 \\
\hline Netherlands & 3.1 & 3.6 & 4.6 & 6.7 \\
\hline Portugal & 6.7 & 8.9 & 12.0 & 16.5 \\
\hline Spain & 11.5 & 8.2 & 19.9 & 28.1 \\
\hline Sweden & 6.0 & 8.1 & 8.6 & 8.0 \\
\hline UK & 5.1 & 5.3 & 7.8 & 7.5 \\
\hline Japan & 5.4 & 3.9 & 5.1 & 4.0 \\
\hline USA & 5.8 & 4.6 & 9.6 & 7.4 \\
\hline
\end{tabular}

Source of data: IMF and Eurostat

In short, the monetary convergence adopted by European policy-makers has not led to real side convergence, as was hoped and expected. On the contrary, real divergences have increased and do not seem likely to start to converge, at least until the world economy returns to the conditions on which the European project was based. 
Before discussing why this is the case, it needs to be pointed out that not only do EMU countries running current account deficit within the Eurozone suffer the burden of re-adjustment within the area. The re-adjustment between the Eurozone and the Dollar zone according to the rules of flexible exchange rates constitutes a further burden and both of these processes lead to recessionary conditions. The Dollar Area is also characterized by a big deficit vis-à-vis the rest of the world ${ }^{13}$.

\section{The Theory of how Automatic Re-Adjustment Works and the EU Project}

\subsection{The Theory of Re-adjustment in the face of External Imbalances}

As we saw above, the main problem facing EMU policy-makers today is that the majority of member countries are running structural surpluses or deficits that are growing over time, and that the policies pursued are in fact increasing, rather than reducing, those disequilibria. The theory of international monetary exchanges indicates that automatic adjustments occur whenever a region of the area is running a surplus and/or a deficit in its balance-of-payments' current account, and continues to operate as long as the disequilibrium remains.

Let us now see how these automatic re-adjustments work utilizing the IS-LM model, customarily adopted to

13 The other two main world economies, China and Japan, follow neo-mercantilist "export-led growth" policies based on the accumulation of currency reserves, mainly denominated in dollars. They can thus avoid re-evaluation of their national currencies and maintain their outstanding current accounts surpluses. 
depict the domestic balance. The construction of the two curves is standard in macroeconomic theory ${ }^{14}$, and is not described in detail here. The starting hypothesis is that the point where the two curves intersect defines the interest rate and the output that lead to internal equilibrium, i.e. full employment as well as the clearing of both the real and the monetary markets of the economies. A further curve, called $\mathrm{BP}$, indicates the points at which external equilibrium (i.e. the situation where the balance of payments is cleared) is also reached. The points along curve BP indicate that in order for external equilibrium to be reached, any increase of output (GDP, labelled Y in the graph) which would increase imports, needs to be matched by an increase in $i$ (domestic interest rate) in order to match the increase in imports with an increase of inward capital flows. The curve is rising, since the slope of the curve depends upon the international mobility of capital flows among countries. Under conditions of perfect capital mobility, the curve would be horizontal ${ }^{15}$, and under conditions of absolutely international immobility of financial capital the curve would be vertical. In Figure 1, the line is almost horizontal to describe the highly international capital mobility of XXI century

14 As usual, the two curves are called:

- IS, which indicates all the pairs of interest rates and levels of output where the real sector of the economy is in equilibrium, in the sense that aggregate demand is equal to aggregate supply; and

- LM, which shows all pairs of interest rates and levels of output where the overall demand for money equals the level of money supply.

15 As in the classical Mundell-Fleming model, from which this model derives (see Fleming, 1962, and Mundell, 1962 and 1968). 
financial markets ${ }^{16}$. All points above $\mathrm{BP}$ are characterized by balance of payments surpluses, as interest rates there are higher than that which would entail an amount of financial flows big enough to equalize the current account balance, which lies beneath it on the BP curve. At this point the balance of financial flows overcomes the current account balance. All points below the BP curve are characterized by balance of payments deficits.

Figure 1 shows what occurs under conditions of fixed exchange rates. There are two countries. The surplus country reaches internal equilibrium at a point where the balance of payments is in surplus, and the deficit country reaches internal equilibrium at a point where there is a balance of payments deficit. The surplus country will receive an amount of money coming from overseas equal to the amount of the surplus, while the deficit country will pay the equivalent of his deficit overseas ${ }^{17}$. So in the surplus country, the money supply increases, which shifts the LM curve, initially from $\mathrm{LM}_{0}$ to $\mathrm{LM}_{1}$ and, if the surplus persists, to $\mathrm{LM}_{\mathrm{z}}$. This puts pressure on the surplus country economy to reduce the domestic interest rate and increase output. The opposite will occur in

16 It should be added expectations play no role in this model, so that spreads do not appear in this analysis. See Footnote 25 for a discussion of the term spread. Of course, changes in expectations and increasing levels of spread among countries are important phenomena in the real world, but this model describes only the comparative statics of the pressures arising from the external imbalances in domestic interest rates and output. It does not describe the dynamics that would follow the discovery of external imbalances by market participants.

17 If they are the only countries included in the model the two amounts will be equal, as is depicted in the graph. But this is only a consequence of the way the graphical representation is depicted and is not relevant to the discussion. 
the deficit country, where money supply decreases, from LM' to $\mathrm{LM}_{1}$, and finally to $\mathrm{LM}_{\mathrm{z}}{ }^{18}$, and the pressure on output is towards reduction.

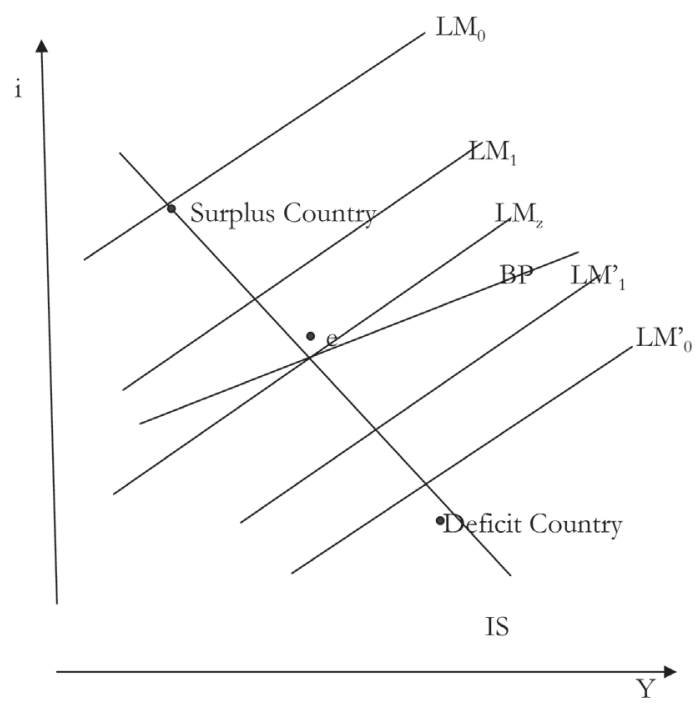

Figure 1 - Automatic re-adjustment under fixed exchange rates in the IS-LM-BP model: Countries in surplus and countries in deficit.

If the initial situation is one of domestic equilibrium in both countries, the re-adjustment of the external imbalance affects the internal equilibria of both. The surplus country, being more competitive, is under expansionary pressure while the deficit country, less competitive, is under contractionary pressure. Neither country can achieve domestic and external

18 For the sake of simplicity, the two countries are assumed to have similar IS and BP curves and LM curves with similar slopes, so that the final equilibrium is the same. Inserting countries with different dimensions and curves into the analysis would not change the qualitative indications provided by the model. 
equilibrium at the same time. The rules of International Monetary Systems deal with these situations, and the previous section briefly discussed the different ways. The Keynes Plan aimed at helping countries to reach domestic and external balance through a Clearing Union whose Central Bank would provide credit facilities to deficit countries. It would have prevented surplus countries from hoarding the surplus, and prevented exchange rates from being modified so as to depreciate the rate of deficit countries and appreciate the rate of surplus countries. The gold standard system tended to raise prices in surplus countries and lower them in deficit countries. The gold exchange standard (Bretton Woods system) could lead to both solutions, with various economists such as Mundell and Fleming arguing in favor of restoring the old gold standard system and Keynesian authors, like Harrod and Kaldor, re-affirming the Keynesian point of view. We noted that the EMU does not follow Keynes' indications, as the Maastricht Treaty does not permit the ECB to lend to member states ${ }^{19}$. Certain economists today are critical of policy today for repeating mistakes and failures similar to those that made the great recession of 80 years ago so harmful. For a recent example see De Grauwe, 2013.

So a real criticism that can be leveled at the EMU project is that it does not provide the means to deal with external imbalances stemming from asymmetric real shocks, like the diverging levels of competitiveness between MS in its first decade. The situation was exacerbated by the fact that EMU countries were under fixed exchange rates amongst themselves but flexible exchange rates between the Eurozone and the

19 In this sense the ECB is, like the International Monetary Fund (IMF) a sort of sui generis Central Bank, having all the characteristics and prerogatives of domestic central banks except that of issuing money. 
rest of the world. In Figure 2 the Mundell-Fleming model re-adjustment theory for this circumstance is shown to include the re-adjustment processes of these years. Figure 2 compares the Eurozone with the Dollar Area. The euro and the dollar are the two currencies most widely used in international trade, and these are the only Monetary Unions ${ }^{20}$ which leave the value of their currencies to be fixed on exchange markets without managing monetary and international reserve policies to alter market exchange rates ${ }^{21}$. At least, they do not use domestic monetary policy to devaluate exchange rates in order to pursue export-led models of growth.

In this case the deficit country is the Dollar Area, while the surplus countries are the members of the Euro Area. Under flexible exchange rates the adjustment set in motion is that the surplus countries will see their currency appreciate, while the deficit countries will see their currency depreciate.

This rule of adjustment therefore entails a reduction in net exports (exports less imports) in surplus countries, where the IS curve shifts to the left and output decreases. The opposite occurs in deficit countries, whose IS curve shifts to the right, increasing aggregate demand and output. The value

20 Of course, the Dollar Area is a currency union consisting of just one country which can manage its own monetary policy as well as its currency autonomously.

21 Especially the yen and the remninbi-yuan. Their exchange rates depend heavily on the policies of the central banks of Japan and China, which often aimed at fixing exchange rates in order to support models of export-led growth. This is a sort of neo-mercantilist revival which conflicts with the supposed nature of flexible exchange rates. It is not generally the case for other important currencies, like the GB pound sterling or the Swiss franc, which are however less significant in the XXI century than in the XX century, and are often used more as shelter currencies when there are high levels of uncertainty on the euro. 
of the euro is therefore kept abnormally high by the enormous surplus accumulated by some European countries, particularly Germany, and by the enormous deficit run by the United States. But the many countries running a deficit within the euro area are suffering from a dual recessionary pressure: on one hand caused by the low level of competitiveness compared to Germany, the leading European exporter, and on the other hand by the high value of the euro, again reflecting high levels of competitiveness of Germany, in this case compared to the rest of the world. As these countries have renounced to the possibility of devaluating their own national currency by adhering to the euro, they suffer from a double pressure to reduce output. This double pressure to recession cannot be solved at national level. It moreover entails a tendency for recessionary conditions to spread from one country to the other MS, as we shall see in the next section.

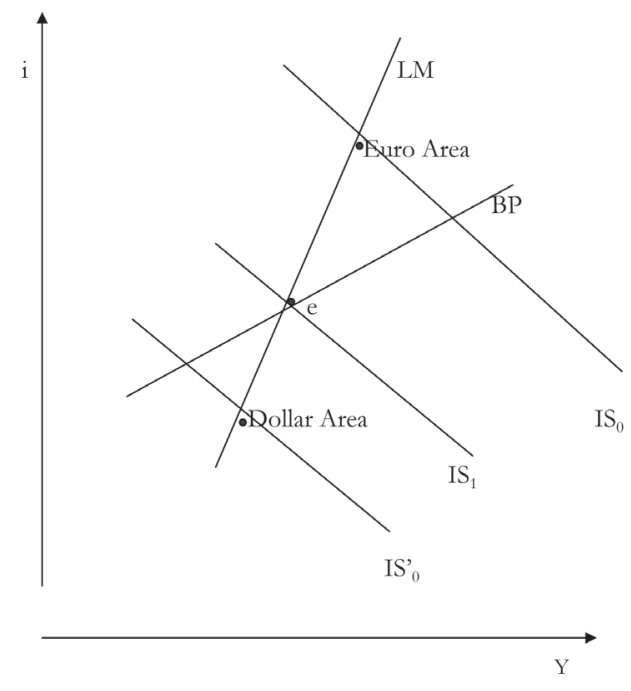

Figure 2 - Automatic re-adjustment under flexible exchange rates in the IS-LM-BP model: Countries in surplus (Euro Area) and countries in deficit (Dollar Area) 


\subsection{The European Union Policy Project after 2010}

The moment of truth for the Eurozone was soon to arrive. In the second quarter of 2010 , the world recession was coming to an end, and the first signs of recovery were appearing. Everywhere governments had avoided the failure of private banking systems (or, at least, of the "banks too big to fail") by injecting into the system large amounts of money and by taking up the burden of a large amount of banks' losses and debts. The cost was a serious increase in public debt: the financial crisis, which had started as a crisis of private banking, became a crisis of public debt. Greece, one of the smallest Eurozone countries, accounting for only $2.5 \%$ of European Union GDP, found that the burden had been too heavy and that it was risking bankruptcy. A country which had not joined a monetary union would not have had any problem, and would have faced the situation by issuing the money needed to remain solvent. It may well have suffered some extent of devaluation, but this would have helped it to restore the external equilibrium. But Greece had abandoned the drachma for the euro and obviously was not able to print this currency. The ECB could not to do so this either, as this measure was forbidden by the Maastricht Treaty, and the euro system provided no way of lending money to MS. The principle of separating monetary from fiscal policies, following monetary policy at joint European level and leaving domestic policy-makers the task of drawing up fiscal policies, made the problem insoluble. It also gave world financial markets the opportunity to speculate against Greece, as had been the case for decades for many currencies under the old Bretton Woods system. Given the uncertainty shown by Eurozone policy-makers ${ }^{22}$ it

22 Eurozone policy-makers took more than one year to solve the situation. A European Financial Stability Facility (EFSF) was set up in June 2010 and charged with financing countries facing financial stability 
was not clear whether intervention could be repeated, especially for larger euro members. Uncertainty spread in financial markets of other Euro countries considered risky, particularly financially solid countries having liquidity problems such as Ireland, Portugal, Italy and Spain. Investors in these countries demanded higher interest rates ${ }^{23}$ than those quoted to other Euro members ${ }^{24}$.

These events showed that the Euro area had become a common monetary area, characterized by the emergence of an inclusive systemic risk, where financial institutions are linked by a network of loans and debts. Under such conditions, if a big financial institution goes bankrupt, its creditors suffer the consequences, and risk bankruptcy themselves (see Soros, 2012). Unfortunately, all EMU countries, both "sinful" and "virtuous", are members of the same Currency Union and the occasional problems of one are spread, through the phenomenon of contagion, to the others. Contagion is both financial and real:

- The creditors of deficit countries are, mainly, the banks of surplus countries: the failure of the deficit countries leads to losses for surplus countries.

- Moreover, the main markets of the surplus countries in the euro area are deficit countries: a failure of the deficit countries means a reduction of the sales of the surplus countries.

problems by buying public bonds in the secondary financial market. But these same policy-makers took one more year to decide, in July 2011, how to intervene in the Greek crisis, and in other crises that had in the meantime appeared in Ireland and Portugal. These interventions used up the entire resources of the EFSF.

23 The convergence of interest rates among Eurozone member states, which favored these countries in the previous phase of the EMU, abruptly reversed.

24 The difference between the interest rates quoted for any public bill issued by a single euro country and the safest among them, those quoted in Germany, has been since then termed "spread". 
So the destinies of all euro countries are linked, and it is vital for European policy-makers to take this into account. If the fate of "sinful" Euro countries were independent from the fate of "virtuous" ones, the lack of solidarity shown by "virtuous" countries would be to some extent understandable. But it should have been very clear to European policy-makers that placing the entire burden of re-adjustment onto weak countries would sooner or later have affected all of them. There is an unavoidable suspicion that the reason why European policy-makers continue to pursue a strategy leading Europe to a complete failure might not only be the idea that putting all the blame, and all the costs, of the re-adjustment on weaker, or "sinful", countries forces them to become virtuous. There is also the suspicion that keeping the two groups separated entails two advantages for the virtuous (or "strong") countries. These possible advantages are:

- the large financial flow leaving the weak countries to be invested in the strong ones (almost 400 billion euro in the three years from mid-2010 and mid-2013).

- the advantage, in terms of higher competitiveness towards the rest of the world, deriving to the strong countries by avoiding the appreciation of domestic currencies that would have occurred had they remained separated from the weak.

Moreover, the rules governing the EU are established by treaties and there is a veritable army of European bureaucrats supervising compliance. There is thus opposition to any change in the rules ${ }^{25}$.

25 The EU project was categorically re-affirmed by a Blueprint published by the European Commission in November 2012 in the middle of the recessionary renewal: "EMU is unique among monetary unions in that it combines a centralized monetary policy with decentral- 
To avoid the spread of this second round of financial crisis, European policy-makers intervened to strengthen the role of the ECB. The bank however was still not permitted to buy newly issued treasury bills, so that the separation between monetary and fiscal policy, the central tenet of the EU project, remained. There have been four main changes to the original project. The first two entailed a program of quantitative easing:

- A program (denominated Long Term Refinancing Operations) carried out between December 2011 and February 2012, consisting of the provision of loans by the ECB to Eurozone banks on extremely favorable terms ( $1 \%$ of annual interest).

- Since September 2012 the ECB has been authorized to carry out "Outright Market Transactions", i.e. buying and selling Treasury bills of Eurozone member states on financial secondary markets. This avoids breaking the rule enshrined in the Maastricht Treaty that prevents the ECB from buying new issued treasury bills in the primary market ${ }^{26}$.

ized responsibility for most <economic policies>" (European Commission, 2012 , p. 2). This bold statement was immediately endorsed by the main European policy-makers (see VAN Rompuy, December 2012).

26 Mid-2014 two other measures of quantitative easing were decided to be carried out in the near future:

- The Tltro (Targeted long term refinancing operations) project, started in September 2014, according to which the ECB will finance at the very low interest rate of $0,15 \%$ per year, commercial banks, up to a maximum of 1 billion euro in four years, to provide banks with incentives to loan to firms and households.

- Buying directly Asset Backed Securities and Residential Mortgage-Backed Securities the ECB will try to revitalize these markets. 
- The EFSF has been substituted by a European Stability Mechanism, which counteracts the increase of spreads by buying public bills, capitalizing banks facing liquidity problems and buying equities from them.

- A surveillance system of all big banks in the euro area by the ECB.

These measures were in addition the strengthening of fiscal control over individual MS described above included in the "Fiscal Compact".

The revision of European economic governance consists basically of three overall measures. This revision was requested by the June 2012 European Council in order to move "towards a genuine economic and monetary union". The blueprint was produced by the European Commission in November 2012 and a Report signed by H.VAN Rompuy, in collaboration with J. M. Barroso, J. C. Juncker and M. Draghi, in December 2012. The measures are: (1) strengthening the restraints on domestic fiscal policy and strengthening of the role of the ECB. The ECB was still not given the role of lender of last resort, but can now support MS deemed solvent but lacking liquidity through Outright Market Transactions). (2) The start of a banking union, aimed at protecting the European banking market, put under the surveillance of the ECB. (3) The further postponement of the start of a fiscal union to the time when all member countries satisfy the fiscal targets decided almost twenty years ago and stated in the Maastricht Treaty. This is in spite of the fact that the major world financial crisis and economic recession have profoundly altered the world economic scene. "Fiscal consolidation" (a term we examine in the following section) was added as a further pre-condition to European fiscal union.

In the meantime the uncertainty that was still determining interest spreads between Euro members was tackled by Mario Draghi, governor of the ECB, in a London speech in 
July 2012 which stated that the ECB would take whatever measures were required to keep the EMU working. Because the uncertainty largely resulted from the spread of negative expectations, this promise was sufficient to limit speculation based on the idea that the euro might be abandoned by some countries. It did not however solve the problem of making the EMU viable. Various economists, including the present author, believe that much more far-reaching measures, such as a real European fiscal union, are required for this.

What appears to be unclear to European policy-makers is that the policy of "virtuous austerity", of which the policy of "fiscal consolidation" is the latest version, are possible only when the world economy is operating under expansionary conditions and when shocks are only monetary, as for example in Germany at the beginning of the XXI century. This policy however is totally unsuited for the present-day situation of a world slowly recovering from recession and with real shocks that have gradually gained ground. Under current conditions Maastricht Treaty institutions and current policy bring the risk of exacerbating cumulative divergences rather than bringing about convergence. This point is discussed in the following section.

\section{The "fiscal consolidation" mistake}

The policy currently implemented by European policy-makers relies on "fiscal consolidation" which is regarded as a preliminary step, a pre-condition, towards fiscal union among Eurozone MS. Fiscal consolidation means implementing the two conditions placed by the Maastricht Treaty on budget deficit and debt to GDP limits. These targets have been strengthened by the three Pacts listed in section 2.3, particularly by the "Fiscal Compact", which aims to oblige all member countries to reach a ratio between Public Debt 
and GDP of $60 \%$. At present no Eurozone member country reaches this target. In fact, the ratio has almost reached a level of $90 \%$ for the European average and ratios are higher ratios in weak countries. Applying the pact would make European fiscal policy recessionary for years to come. Moreover, the plan seems unlikely to be effective, as it relies heavily on the two conditions at the heart of the theory on which the EMU was built, but questionable at the time when the EMU was conceived and far from being satisfied now. One condition is the "crowding out" hypothesis and the other the Lisbon strategy. The plan also relies on the hope that the world will rapidly recover an expansionary trend, in which real shocks are absent or easily resolved through supply policy measures. A final weakness of the plan is what De Grauwe and Ji (2013) have called the "fallacy of composition problem": it is a plan that might work if carried out by a single country, but given that the effects of austerity are cumulative, will probably fail if carried out by all or a majority of European countries.

Let us treat the issue using algebra ${ }^{27}$.

In what follows: Debt stands for public debt and GNP is the gross national product (Both are measured in nominal terms, i.e. in euro); $\mathrm{d}$ is the ratio between Debt and GNP; FC is the amount of fiscal consolidation (percentage of either increase of taxes or decrease of public expenses compared to GNP) used as an instrument by policy-makers to achieve the target of reducing $d$ (the ratio between Debt and GNP); $\Delta$ indicates a percentage change. The problem illustrated below is how policy makers decrease $\mathrm{d}$ by acting on FC.

27 The model was provided by professors Giancarlo Gandolfo and Domenico Mario Nuti and published by Nuti (Nuti, 2013). 
By definition:

$$
\Delta \mathrm{Debt}=-\mathrm{FC} \cdot \mathrm{GNP}
$$

and

$$
\Delta \mathrm{GNP}=- \text { Multiplier } \cdot \mathrm{FC} \cdot \mathrm{GNP}
$$

Where Multiplier is the appropriate fiscal multiplier (i.e. the number of times GNP increases/decreases as a consequence of a unitary increase/decrease of a public budget item) ${ }^{28}$. Hence:

$=[(\Delta \mathrm{Debt}) \cdot \mathrm{GNP}-(\Delta \mathrm{GNP}) \cdot \mathrm{Debt}] / \mathrm{GNP}^{2}=$

$=[(-\mathrm{FC} \cdot \mathrm{GNP}) \cdot \mathrm{GNP}-(-$ Multiplier $\cdot \mathrm{FC} \cdot \mathrm{GNP}) \cdot \mathrm{Debt}] / \mathrm{GNP}^{2}=$ $=-\mathrm{FC} \cdot\left(\mathrm{GNP}^{2} / \mathrm{GNP}^{2}\right)+($ Multiplier $\cdot \mathrm{FC} \cdot \mathrm{GNP} \cdot \mathrm{Debt}) / \mathrm{GNP}^{2}=$ $=-\mathrm{FC}+($ Multiplier $\cdot \mathrm{FC} \cdot \mathrm{Debt}) / \mathrm{GNP}=$

$=\mathrm{FC} \cdot[$ Multiplier $\cdot($ Debt $/ \mathrm{GNP})-1]=$

$=\mathrm{FC} \cdot($ Debt $/ \mathrm{GNP}) \cdot[$ Multiplier $-(1 /(\mathrm{Debt} / \mathrm{GNP})]$.

The conclusion is that $\mathrm{d}$ (the ratio between Debt and GNP) will decrease if, and only if, the value of the Multiplier is lower than the inverse of $\mathrm{d}$. In this case the effects of reducing public expenditure and/or increasing taxes (both depressing GNP) are overcome by the reduction of public debt due to the advance of the public surplus. If this condition is not fulfilled, the fiscal consolidation strategy leads to precisely the opposite result to the one it aimed at: the GNP decrease is higher than the reduction of public debt.

28 Of course, there are different multipliers for various budget items. The overall value indicated in the formulae is a weighted average. 
Under the hypothesis that a reduction in public expenditures is to a great extent substituted by an increase in private investments, the multiplier is low. This hypothesis is the "crowding out", posited by "new classical macroeconomic theory" and on which the EU project was designed. According to econometric estimates made at the beginning of the XXI century, the multiplier was in fact about 0.5 or lower, but it has risen rapidly with the world recession. Numerous International Monetary Fund economists provided impressive results, summarized in a Box included in the 2012 IMF publication World Economic Outlook. Blanchard and Leigh (2013) found values of fiscal multipliers after 2010 ranging between 0.9 and 1.7; Auerbach and Gorodnichenko (2012) found that fiscal multipliers in boom periods show values near to zero but reach values as high as 2.5 during recessions ${ }^{29}$. This explains why a policy of austerity, although it was a success in Germany at the beginning of the century, will not work until the world economy is restored to the situation of those years. In spite of this, however, austerity is still being put forward by European policy-makers as a model to weak countries. In their paper on the present situation of Eurozone countries, De Grauwe and Ji (2013) estimate a fiscal multiplier of $1.4 \%$. This means that a $1 \%$ increase in austerity leads to only a $0.5 \%$ improvement in the budget balance, and implies a drop in GDP of 2.8\%. This would entail an enormous sacrifice for countries that were adopting austerity: their Debt/ Public Deficit ratio, rather than decreasing is likely worsen seriously.

29 As far back as the 1950s and 1960s, Keynesian economists pointed out that multipliers are much higher in recession than in boom periods and that consequently expansionary fiscal policies are much more effective. The point appears to have been forgotten today. 
Moreover, effects are different according to whether fiscal consolidation is pursued through tax increases or through public expenditure cuts. If tax increases are used, fiscal multipliers are low, ranging between 0.16 and 0.35 , as estimated by BATini et al., and the cost of consolidation is probably bearable. But if public spending is cut, Batini et al. estimate that fiscal multipliers are almost ten times higher and the cost of consolidation becomes unbearably high. It should be remembered that cutting public spending is the strategy usually suggested by European policy-makers.

Finally, a prolonged recession destroys productive capacity, making growth more difficult, and makes the cost of fiscal consolidation even heavier. During a prolonged recession, entrepreneurs do not invest, and productive capital is not replaced. As Nicholas KALDOR frequently noted, it in fact decreases. The same is true for human capital: unemployed workers lose contact with the market and often stop searching for a job, and their productivity inevitably decreases. This was noted by Fernando Vianello (2005) in an early examination of the ideas leading to the "virtuous austerity" program. In fact it seems clear that Eurozone countries have paid dearly for the seven years of recession and lack of growth since 2007. Investments across the Eurozone have decreased by $18 \%$ on average and by more in southern countries; unemployment has doubled on average, and more than doubled in some southern countries.

Briefly, adopting an austerity program under the present conditions entails an initial increase in the Debt/GNP ratio. This increase would end only in the case of a robust world expansion and only if the "Lisbon strategy" succeeded. These two conditions however are far from being met. In the meantime, fiscal consolidation is a costly way to gain time by trying to reassure international financial markets that Eurozone countries are willing to make sacrifices in order to guarantee 
that they will never abandon the Euro. The question of whether it would be preferable to send the markets this message through the construction of a solid Union is discussed in the last section.

\section{What should be done instead?}

A situation similar to the one faced now by the Eurozone was faced by the Western world 65 years ago, at the end of the 1940s, when the Bretton Woods system came into being. World War II had ended leaving the USA with an enormous technical and economic advantage and the European countries in a total disarray. The Bretton Woods measures, although not as harsh as Maastricht Treaty provisions, were not bold enough to lead to a lasting world expansion. The USA could not be other than the surplus country par excellence and may have suffered a measure of guilt for omitting in the Bretton Woods Treaty Keynes' suggestion not to burden debtor countries with the entire cost of re-adjustment. The USA in fact offered European countries the Marshall Plan, consisting of help, assistance, transfers and loans at low rates, which made it possible for countries almost destroyed by the World War II, particularly Germany ${ }^{30}$, to make the most impressive economic recovery in world history.

Ideally the EMU should follow this example today, and this would be the first best solution suggested by the theory put forward above. This would prevent the euro area undergoing a crisis that would probably spread from the countries now in difficulty to the rest of the area, transforming today's

30 The United States even persuaded other European countries, particularly Greece, heavily damaged by World War II, to renounce war damage payments so that Germany might start her process of export led economic growth, which has continued to the present day. 
European stagnation into the expansion that the making of the Economic Union had promised. This solution, whose main building blocks are summarized below, would imply expansion "the EMU into a Political Union" (Habermas, 2013, p. 6). Professor Jürgen Habermas, in the Lecture he delivered on 26 April 2013 in Leuven, called for the EU to be turned into a "supranational democracy". Habermas criticized as a technocratic fault by European policy-makers that they "preserve the euro without taking further political steps to closer integration". Habermas identifies in the "lack of solidarity" among member countries deriving from this technocratic approach, "the major hindrance" to his proposal to make "a cooperative effort from a shared political perspective to promote growth and competitiveness in the euro zone as a whole". He of course recognizes, that "such an effort would require Germany and several countries to accept short-and medium-term negative redistributions effects in its own longer-term self-interest" (Habermas, 2013, p. 6). One cannot but agree with Habermas's proposal ${ }^{31}$. Unfortunately,

31 On the contrary, if European policy-makers do not feel the solidarity required to adopt such measures, we believe there is only one solution: euthanasia of EMU, and probably of EU too. As George Soros (2012) put it recently: "Germany has to lead Europe or to leave it". In the event of Germany leaving, two provisions should be adopted in order to minimize negative fall-out:

- All bonds issued in euro should be redenominated in the national currency at the exchange rate at which any country joined the EMU.

- To minimize the speculation which would accompany the move, Germany should be the first country to leave the Union.

Both these conditions are quite unlikely to be satisfied if the Euro Area disappeared, which makes the problems of the Euro even more 
the current situation European policy-makers have put themselves in is a "Catch 22" 32: "Any euro member state can rely on the support of all the others provided it demonstrates that it does not need such support".

We have already noted that the problems faced by Eurozone countries and the solutions proposed by European policy-makers are increasingly coming to resemble those of the 1940s. It was 80 years ago that John Maynard Keynes wrote his "Open letter to President Roosevelt", published in the New York Times on 31 December 1933. He wrote that in order to recover, the (Western) world needed to

"put in the forefront...a large volume of loan-expenditure under government auspice...for example the rehabilitation of the physical condition of the railroads. The object is to start the ball rolling...I put in the second place the maintenance of cheap and abundant credit and in particular the reduction of the long-term rates of interest".

Two years later, having savored the success of the "New Deal", Keynes wrote, challenging the opposing point of view, that in economic depression it would even be better

"to fill old bottles with banknotes, bury them at suitable depths in dismissed coalmines... and leave it to private enterprises to dig the notes up again ... there need be no more unemployment and the real income of the community would probably became a good deal greater than it actually is. It would, indeed, be more sensible to build houses and the like, but if there are political

pressing, as the cost of abandoning the Monetary Union would be dreadful for all country members.

32 Joseph Heller's 1950s novel. 
and practical difficulties in the way of this, the above would be better than nothing" 33 (KeYNes, 1936, p. 129).

Nowadays, the only way to escape from the labyrinth we have described is for European policy-makers to adopt a program based on three building-blocks: (1) A program of public investments in the infrastructure needed to improve the technological level of Europe ${ }^{34}$, financing it by an issue of Eurobonds. This issue would have the further advantage of convincing financial markets that the euro is here to stay. (2) Obliging both surplus and deficit countries to make the adjustments necessary to correct external imbalances in the euro area. (3) Taking the initial steps towards a budgetary union, without which a purely monetary union does not work. This might be the only way to prevent perverse downward spiral "fiscal consolidation - recession — investment reduction - more recession". This is a solution developed by Keynes for the 1930 that has rarely been taken seriously by economists accustomed to the almost full employment of the second half of the XX Century. But if the "fiscal compact project" is carried out without world-wide full employment, this solution might become the only one possible for Europe today.

33 Practitioners of the common sense (mainstreaming) theory have for 80 years continued to attack this voluntarily paradoxical version of Keynes' theory rather than the previous most serious version.

34 Nowadays, the infrastructures required in Europe, necessitated by the Lisbon Strategy and other factors, are in digital communications, transport and the environment. 


\section{Bibliography}

Auerbach, A. and Y. Gorodnichenko (2012): "Fiscal Multipliers in Recession and Expansion", in A. Alesina e F. Giavazzi: Fiscal Policy after the Financial Crisis, University of Chicago Press.

Batini, N.; Callegari, G.; G. Melina (2012): "Successful Austerity in the United States, Europe and Japan” IMF Working Paper, 12/190; Washington, July.

Blanchard, O. J.; D. Leigh (2013): “Growth Forecast Errors and Fiscal Multipliers", IMF Working Paper Series, 1/2013; Washington, January.

Corden, W. M. (1972): “Monetary Integration”, Princeton Essays in International Finance, n. 93; Princeton University, International Finance Section.

De Grauwe, P. (1992): The Economics of Monetary Integration (1 ${ }^{\text {st }}$ Edition: 1992, $7^{\text {th }}$ edition: 2007); Oxford University Press.

(2011): "The Governance of a Fragile Eurozone", CEPS Working Documents, $n .^{\circ}$ 346/2011, May; http//ceps.eu.

- (2013): "Design Failures in the Eurozone: Can they be fixed?", LEQS Paper n. ${ }^{\circ}$ 57/2013, February; http//www.lse.ac.uk/European institute/leqs.

—_ JI,Y. (2013): "Panic-driven Austerity in the Eurozone and its Implications"; http//www.voxeu.org/article/panic-driven-austerity-eurozone-and-its-implications.

European Commission (2012): A Blueprint for a Deep and Genuine Economic and Monetary Union. Launching a European Debate; Brussels, $30 / 11 / 2012$

Fleming, J. M. (1962): "Domestic Financial Policies under Fixed and Floating Exchange Rates”, IMF Staff Papers, vol. IX, pp. 369-379.

Friedman, M. (1953): "The Case for Flexible Exchange Rates", in M. Friedman (ed.): Essays in Positive Economics; University of Chicago Press; pp. 157-203.

Habermas, J. (2013): Democracy, Solidarity and the European Crisis (Lecture delivered on 26 April 2013 in Leuven); <http://www.kuleuven. be/communicatie/evenementen/jurgen-habermas/democracy,soli darityandtheeuropeancrisis $>$.

Heller, J. (1955): Catch-22, Dell Publishing Co. Inc.; New York.

ILO (International Labor Organization) (2013): Global Wage Report 2012-2013: Wages and Equitable Growth; Génève.

IMF (International Monetary Fund) (2012): “Box 1.1. Are We Underestimating Short-Term Fiscal Multipliers?" in World Economic Outlook - Coping with High Debt and Sluggish Growth, pp. 41-43; Washington, October. 
Kaldor, N. (1971): “The Dynamic Effects of the Common Market”, New Statesman, 12 $2^{\text {th }}$ March 1971, reprinted in Further Essays on Applied Economics - Collected Economic Essays, vol. 6, Duckworth, London.

Kaldor, N. (1983): "The Role of Effective Demand in the short run and the long run”, in F. Targetti and A.P. Thirlwall, Eds. (1989): Further Essays on Economic Theory and Policy - Collected Economic Essays, vol. 9, Duckworth, London.

Kenen, P. B. (1969): “The Theory of Optimum Currency Areas: An Eclectic View”, in R.A. Mundell and A. K. Swoboda (eds.): Monetary Problems of the International Economy; Chicago University Press; pp. 41-60.

Keynes, J. M. (1936): The General Theory of Interest and Money, The Mc Millan Press, London.

— (1943): "Proposals for an International Clearing Union", British Government Publications, Cmd. 6437. Reproduced in H. G. Grubel (ed.): World Monetary Reforms. Plans and Issues; Stanford University Press, Stanford, California (1964), pp. 56-79.

McKinnon, R. I. (1963): “Optimum Currency Areas”, American Economic Research, vol. LII; pp. 717-725.

Meade, J. E. (1957): “The Balance of Payments Problems of a Free Trade Area”, Economic Journal, September, vol. CXVII; pp. 379-396.

Mundell, R. A. (1961): "A Theory of Optimum Currency Areas", The American Economic Review, vol. LI, N. ${ }^{\circ}$ 4, September; pp. 657-665.

- (1962): "The Appropriate Use of Monetary and Fiscal Policy under Fixed Exchange Rates”, IMF Staff Papers, vol. IX; pp. 70-79.

- (1968): International Economics, The MacMillan Press, London.

Nuti, D. M. (2013): "Gli effetti perversi del consolidamento fiscale"; $<$ http//www.sbilanciamoci.info/Sezioni/globi $>$.

Soros, G. (2012): Financial Turmoil in Europe and the United States; Perseus Books Group, New York.

Skidelsky, R. and V. Joshi (2010): "Keynes, Global Imbalances, and International Monetary Reform, Today", in S. Claessens, S. Evenett and B. Hoeckman (eds.): Rebalancing the Global Economy: A Primer for Policymaking; <http//voxeu.org/epubs/cepr-reports>.

Van Rompuy, H. (in close collaboration with: J. M. Barroso, J. C. Juncker and M. Draghi) (2012): Towards a Genuine Economic and Monetary Union; Bruxelles, 5 December 2012.

Vianello, F. (2005): "La Moneta Unica Europea", mimeo, reprinted in Economia \& Lavoro (2013). vol. XLVII, n. ${ }^{\circ}$ I; pp. 27-46. 
Abstract:The Eurozone was hit by the world economic crisis of 2008 more severely than any other part of the world and now risks falling back into recession. In this paper I will argue that the reason for its poor performance is that under a fixed exchange-rate régime - of which a Monetary Union is an extreme version - monetary policy is effective in recovering equilibrium only after money shocks. In the face of real shocks, like the ones produced by the world recession of 2008-2010, either some kind of exchange rate flexibility or public measures able to correct the effects of the shocks without leading the area into recession are required. None of the policy measures indicated by the economic theories of re-adjustment in the face of external imbalances and by the optimum currency area theory have been followed in building the EMU. EMU was claimed by the European Commission to be "unique among monetary unions in that it combines a centralized monetary policy with a decentralized responsibility for most <economic policies>", but it is not working properly. Using a simple model the conclusion is reached that the policy of "virtuous austerity" currently carried out in the Eurozone is effective only when the world economy is operating under expansionary conditions and when shocks are only monetary. This policy however is totally unsuited for the present-day situation of a world slowly recovering from recession and with real shocks that have gradually gained ground.

Keywords: International Monetary Arrangements and Institutions (F33); open economy macroeconomics (F41); international institutional arrangements (F55); economic integration (F15); International Policy Coordination and Transmission (F42); European Monetary Union; Eurozone policy program; Optimum Currency Areas theory; the theory of international monetary re-adjustment.

Mario Biagioli ${ }^{35}$

Dipartimento di Economia, Università degli Studi di Parma — Italia

35 The author is grateful to Emiliano Brancaccio, Giuseppe Celi, Bruno Salituro, Augusto Schianchi, Giovanni Verga for comments and suggestions. A preliminary version of this paper was presented at the Jean Monnet International Conference held in the university of Ştefan cel Mare, Suceava, 10-13 July 2013. 